\title{
Surto de encefalomielite equina Leste na Ilha de Marajó, Pará ${ }^{1}$
}

\author{
Karinny F. Campos ${ }^{2}$, Cairo H.S. De Oliveira ${ }^{3}$, Alessandra Belo Reis ${ }^{2}$, Elise M. Yamasaki ${ }^{4}$, \\ Marilene de Farias Brito ${ }^{5}$, Stefano Juliano T. Andrade ${ }^{2}$, Marcos Dutra Duarte $^{2}$ \\ e José D. Barbosa ${ }^{2 *}$
}

\begin{abstract}
Campos K.F., De Oliveira C.H.S., Belo Reis A., Yamasaki E.M., Brito M.F., Andrade S.J.T., Duarte M.D. \& Barbosa J.D. 2013. [Eastern equine encephalitis on Marajó Island, Pará state, Brazil.] Surto de encefalomielite equina Leste na Ilha de Marajó, Pará. Pesquisa Veterinária Brasileira 33(4):443-448. Central de Diagnóstico Veterinário, Faculdade de Medicina Veterinária, Universidade Federal do Pará, Campus Castanhal, Rua Maximino Porpino da Silva 1000, Castanhal, PA 68740-080, Brazil. E-mail: diomedes@ufpa.br

Nine cases of equine encephalomyelitis on Marajó Island, state of Pará, Brazil, were studied. The affected horses had difficulty to stand, walked in circles, with marked depression, closed eyelids, tongue paralysis, muscle tremors, bruxism, anorexia and dehydration. Some had their ear and eyelid reflexes diminished, decreased tongue tone and tachycardia; laid down frequently they kept their head on the chest. Often they were seen resting their head on tree trunks or fences. At necropsy, hemorrhages of the meninges and spinal cord, and in some animals also adhesion of the meninges were found. Histologically there was diffuse encephalitis affecting mainly the gray matter, with meningitis and choroiditis. Presence of perivascular cuffs consisting of mononuclear inflammatory cells was observed. From two horses the Eastern equine encephalitis virus was identified by semi-nested reverse transcription polymerase chain reaction (semi-nested RT-PCR).
\end{abstract}

INDEX TERMS: Equine encephalitis, Eastern equine encephalitis virus, Marajó Island.

RESUMO.- Nove casos de encefalomielite equina foram estudados na Ilha de Marajó, estado do Pará, Brasil. Os equinos apresentavam dificuldade em se manter em estação, andavam em círculo, tinham acentuada depressão, pálpebras cerradas, paralisia da língua, tremores musculares, bruxismo, anorexia e desidratação. Alguns apresentavam diminuição dos reflexos auricular, palpebral, de ameaça, diminuição do tônus da língua e taquicardia. Posição de auto-auscultação foi observada com frequência. Os animais muitas vezes eram encontrados apoiados em troncos e cercas para se manterem

\footnotetext{
${ }^{1}$ Recebido em 4 de outubro de 2012.

Aceito para publicação em 19 de fevereiro de 2013

${ }^{2}$ Central de Diagnóstico Veterinário, Faculdade de Medicina Veterinária, Universidade Federal do Pará (UFPA), Campus Castanhal, Rua Maximino Porpino da Silva 1000, Centro, Castanhal, PA 68740-080, Brasil. *Autor para correspondência: diomedes@ufpa.br

${ }^{3}$ Programa de Pós-Graduação em Ciência Animal, Escola de Veterinária, Universidade Federal de Minas Gerais (UFMG), Av. Antônio Carlos 6627, Pampulha, Belo Horizonte, MG 31270-901, Brasil.

${ }^{4}$ Curso de Pós-Graduação em Ciência Veterinária, Universidade Federal Rural do Rio de Janeiro (UFRRJ), Seropédica, RJ 23890-000, Brasil.

${ }^{5}$ Departamento de Epidemiologia e Saúde Pública, Instituto de Veterinária, UFRRJ, Seropédica, RJ.
}

em estação. À necropsia verificou-se hemorragia das leptomeninges e da medula, alguns apresentaram ainda aderência das leptomeninges. À histopatologia verificou-se encefalite difusa que afetava principalmente a substância cinzenta, com meningite e coroidite. Foi observada perivasculite mononuclear. Em dois equinos identificou-se o vírus da encefalomielite equina Leste pela reação de Semi-Nested transcrição reversa de polimerase em cadeia (Semi-Nested RT-PCR).

TERMOS DE INDEXAÇÃO: Encefalomielite equina, vírus da encefalomielite equina Leste, Ilha de Marajó.

\section{INTRODUÇÃO}

A encefalomielite equina Leste (EEL) é uma doença viral causada pelo Eastern equine encephalitis virus (EEEV), um RNA vírus do gênero Alphavirus pertencente à família Togaviridae. A doença manifesta-se com sintomatologia nervosa; é considerada uma zoonose de alta letalidade (Fields et al. 1996, Thomassian 1996, Barros 2007).

A transmissão da EEL ocorre com um ciclo básico silvestre (entre aves silvestres), que envolve a participação de mosquitos do gênero Culex e um segundo ciclo em pássaros locais, do qual participam mosquitos do gênero $A e-$ 
des. 0 homem e o equino são hospedeiros acidentais e não contribuem para a manutenção do vírus, assim como suínos, ovelhas, cães e demais espécies, nas quais o vírus vem sendo identificado (Elvinger et al. 1994, Bauer et al. 2005, Farrar et al. 2005, Kotait et al. 2006). Na Amazônia o vírus da EEE foi isolado tanto a partir de aves silvestres como de mosquitos dos gêneros Aedes sp., Culex sp. e Mansonia sp. (Vasconcelos et al. 1991)

Além do EEEV, têm sido isolados ou detectados sorologicamente os vírus Western equine encephalitis virus (WEEV) e o Venezuelan equine encephalitis virus (VEEV). As doenças causadas são denominadas respectivamente encefalite equina do Oeste (EEO) e encefalite equina Venezuelana (EEV) e assim como a EEL, receberam essa denominação de acordo com a localização de sua primeira identificação (Barros 2007).

No Brasil, trabalhos de sorologia do EEEV em equinos foram realizados por Carneiro (1937), Lannette \& Fox (1943), Nilsson \& Sugay (1962), Vasconcelos et al. (1991), Kotait et al. (1992), Iversson et al. (1993), Fernández et al. (2000), Heinemann et al. (2006), Cunha et al. (2009) e Casseb (2010). A doença com descrição do quadro clínico-patológico em equinos com diagnóstico confirmado com isolamento do vírus foi relatada, no Brasil, apenas por Pimentel et al. (2009), em Pernambuco e por Silva et al. (2011) nos estados de Pernambuco, Ceará e Paraíba. Não há descrição da doença em equinos com identificação do vírus na Região Norte do Brasil, especialmente na Ilha de Marajó. Em levantamento sorológico para arbovírus, inclusive EEEV, Casseb (2010) incluiu algumas amostras de equinos procedentes da Ilha de Marajó, com resultados positivos para os diferentes tipos de vírus da encefalomielite equina.

A doença tem grande importância na saúde pública, com relatos de complicações neurológicas graves e óbitos em humanos (Alice 1956).

A Ilha de Marajó, no estado do Pará, é uma ilha de 49.000 $\mathrm{km}^{2}$ de área, constituída de floresta equatorial e campos naturais onde vive o maior rebanho de búfalos do Brasil e um grande rebanho de gado bovino e equino (Cardoso \& Pereira 2002).

0 objetivo desse estudo é relatar um surto de encefalomielite equina em equinos, descrever o quadro clínico-patológico, bem como identificar o agente viral no município de Cachoeira do Arari, Ilha de Marajó, Pará.

\section{MATERIAL E MÉTODOS}

O estudo foi realizado no município de Cachoeira do Arari, Ilha de Marajó, estado do Pará, entre os meses de junho a setembro de 2009. O clima da ilha segundo a classificação de Köppen é do tipo tropical chuvoso Ami, com precipitação média anual de $2500 \mathrm{~mm}$, temperatura média de $27^{\circ} \mathrm{C}$, umidade relativa de $85 \%$, com pluviosidade distribuída em dois períodos distintos: um de máxima de janeiro a junho e outro de mínima de setembro a novembro. A maior intensidade das chuvas, no entanto, acontece de fevereiro a maio e é tamanha que dois terços de Ilha de Marajó ficam completamente alagados (Cardoso \& Pereira 2002).

Foram visitadas sete propriedades rurais com o objetivo de identificar equinos acometidos pela enfermidade. Foi realizado o exame clínico completo dos animais com ênfase no sistema nervoso. Acompanhou-se clinicamente oito equinos.
Foram necropsiados quatro animais (Equinos 1, 3, 5 e 6) que apresentaram sinais clínicos da enfermidade. Fragmentos de diversos órgãos foram coletados, fixados em formol a 10\%, processados rotineiramente para exame histopatológico, incluídos em parafina, cortados a $5 \mu \mathrm{m}$, corados pela hematoxilina-eosina (HE) e examinados no Setor de Anatomia Patológica do Projeto Sanidade Animal, Universidade Federal Rural do Rio de Janeiro (UFRRJ).

Coletou-se dos Equinos 3, 5, 6 fragmentos de diversas regiões do sistema nervoso central (cérebro, cerebelo, tronco encefálico e medula). Esse material foi acondicionado em tubos de polietileno (tipo ependorff), refrigerado e remetido à Seção de Diagnóstico do Instituto Pasteur em São Paulo, onde foram realizados os testes de Imunofluorescência Direta (IFD) e a Inoculação Intracerebral em Camundongos (IIC) para realização do diagnóstico diferencial com raiva. Para o diagnóstico dos agentes causadores das encefalomielites equina, os fragmentos de cérebro foram submetidos à RT-PCR e, posteriormente, à NESTED-PCR.

A extração de RNA foi realizada pelo método do Trizol ${ }^{\circledR}$ segundo orientações do fabricante, a partir do SNC dos equinos. A extração foi realizada de um pool de tronco encefálico e cerebelo, e em três equinos, de medula cervical, hipocampo e córtex frontal. Como controle positivo foi utilizado uma amostra de vírus fixo de EEO, cedido pelo Instituto Evandro Chagas (IEC) e mantido em camundongos albinos suíços. Como controle negativo foi utilizada água ultra pura livre de DNAse e RNAse. Os controles positivo e negativo, juntamente com as amostras de SNC foram submetidas à técnica de Semi-Nested RT-PCR dirigida para a amplificação de um fragmento de 310 pares de base (nucleotídeos 283 a 592) da proteína não estrutural 1 (NSP1) do gênero Alphavirus, segundo protocolo descrito por Pfeffer et al. (1997).

Na reação de Semi-Nested PCR foi utilizado um controle negativo para as amostras testadas, visando um maior controle sobre possíveis contaminações da reação. Os primers utilizados na Semi-Nested RT-PCR encontram-se descritos no Quadro 1. 0 frag-

Quadro 1. Descrição dos primers usados no Semi-Nested RT-PCR

\begin{tabular}{ccclc}
\hline Primer & Sentido & Utilizado & \multicolumn{1}{c}{ Sequência } & $\begin{array}{c}\text { Posição no } \\
\text { genoma }\end{array}$ \\
\hline A1 & Sense & RT-PCR & 5'AGAGCDTTTTCGCAYS- & $\begin{array}{c}\text { Nucleotide } \\
\text { TRGCHW 3' }\end{array}$ \\
& & & 159-180 \\
A2 & Antisense & RT-PCR/Semi- & 5'ACATRAANKGNGTNG- & Nucleotide \\
& & Nested PCR & TRTCRAANCCDAYCC 3' & 563-592 \\
A3 & Sense & Semi-Nested & 5'TGYCCNVTGMDNWSY- & Nucleotide \\
& & PCR & VCNGARGAYCC 3' & 283-308
\end{tabular}

mento de 310 pb resultante da Semi-Nested RT-PCR foi purificado a partir de géis de agarose a $1 \%$, com o Kit QIAquick ${ }^{\circledR}$ Gel Extraction Kit e quantificados com Low DNA Mass Ladder (Invitrogen) em gel de agarose a $2 \%$, segundo instruções dos fabricantes.

Para descartar as possibilidades de infecção pelo vírus da raiva, foi realizado o teste de imunohistoquímica. As secções foram incubadas com anticorpo contra raiva (Rabies Polyclonal, Light Diagnostics, USA) numa diluição de 1:1000; utilizou-se kit comercial (LSAB-AP, Dako), técnica de avidina-biotina fosfatase-alcalina e a reação foi revelada com o cromógeno Permanent-red (Dako). Como controle positivo foi utilizado fragmento histológico de SNC de bovino com presença de corpúsculo de Negri, perivasculite mononuclear e marcação positiva no teste de IHQ contra raiva.

Para cada reação de sequenciamento de DNA foram utilizados entre 2,5 a 10ng de DNA. Os fragmentos de DNA foram submetidos ao sequenciamento bidirecional de DNA, com os primers A2 e A3 em reações separadas, utilizando-se o kit BigDye® Terminator v3.1 Cycle Sequencing Kit (Applied Biosystems). 
A purificação da reação de sequenciamento foi realizada por Sephadex ${ }^{\mathrm{TM}}$ G-50 (GE healthcare Bio-sciences), em placas com filtro Multiscreen HV com 96 orifícios. Após a purificação, as sequências foram geradas em analisador genético automático ABI3130 (Applied Biosystems ${ }^{\mathrm{TM}}$ ).

A confirmação do sequenciamento e determinação da espécie viral foi realizada através do aplicativo BLASTn (http://www. ncbi.nlm.nih.gov/BLAST). Foi realizada a identificação do vírus pelo Semi-Nested RT-PCR em dois animais (Equinos 5 e 6).

\section{RESULTADOS}

Há alguns anos proprietários de fazendas na Ilha de Marajó relatam a ocorrência de morte de equinos com sinais clínicos neurológicos na época das chuvas, que compreende os meses de janeiro a junho. Durante uma visita técnica a uma destas propriedades, localizada no município de Cachoeira do Arari, foi observado um equino, macho, da raça marajoara e idade aproximada de dois anos, em decúbito lateral, que apresentava extrema dificuldade de se manter em estação, quedas, apatia, anorexia e diminuição do reflexo lingual; esse equino morreu cinco dias após o início dos sinais clínicos. A suspeita clínica era de raiva, porém, os tratadores relataram a recuperação de animais que apresentaram sinais semelhantes, além de sinais mais brandos e que vários equinos de propriedades vizinhas apresentavam o mesmo problema. A doença é popularmente conhecida na região como "mormo de roda", já que os vaqueiros encontravam os animais andando em círculo nos campos naturais da região. Durante os surtos nos meses de abril, maio e junho de 2009 foram realizadas outras visitas técnicas para estudo dos casos.

Foram estudados nove equinos oriundos de sete propriedades. Os animais acometidos eram de ambos os sexos, com idades entre seis meses e 11 anos, oito da raça Marajoara e um da raça Puruca.

Dados epidemiológicos de morbidade, mortalidade e letalidade foram de difícil obtenção devido à falta de confiabilidade nas informações prestadas, além da característica da Ilha de Marajó em que animais de várias propriedades são criados extensivamente e vivem juntos pela ausência de cercas nas propriedades. Dos nove animais estudados, quatro recuperaram-se. Todos os animais estudados eram provenientes de propriedades que não realizavam vacinação contra o EEEV, raiva ou outras doenças.

No Quadro 2 constam os dados sobre os equinos atendidos, da situação em que se encontravam durante o atendimento e do desfecho de cada caso.

0 Equino 1 encontrava-se na fase inicial da enfermida- de. Os sinais clínicos observados foram anorexia, hipermetria, dificuldade de locomoção, andar em circulo e escoriações na pele da região da cabeça.

Os Equinos 2, 3 e 4 apresentaram quadro clínico grave. O Equino 2 encontrava-se em decúbito lateral, tinha extrema dificuldade de colocar-se e manter-se em estação e sofreu várias quedas. Também foram observados ataxia, apatia, anorexia e diminuição do reflexo lingual; esse equino morreu cinco dias após o início dos sinais clínicos.

No Equino 3, os sinais clínicos consistiram em acentuada depressão, dificuldade em manter-se em estação; o animal permanecia por longos períodos parado no mesmo lugar (Fig.1) ou em decúbito lateral (Fig.2), ora com

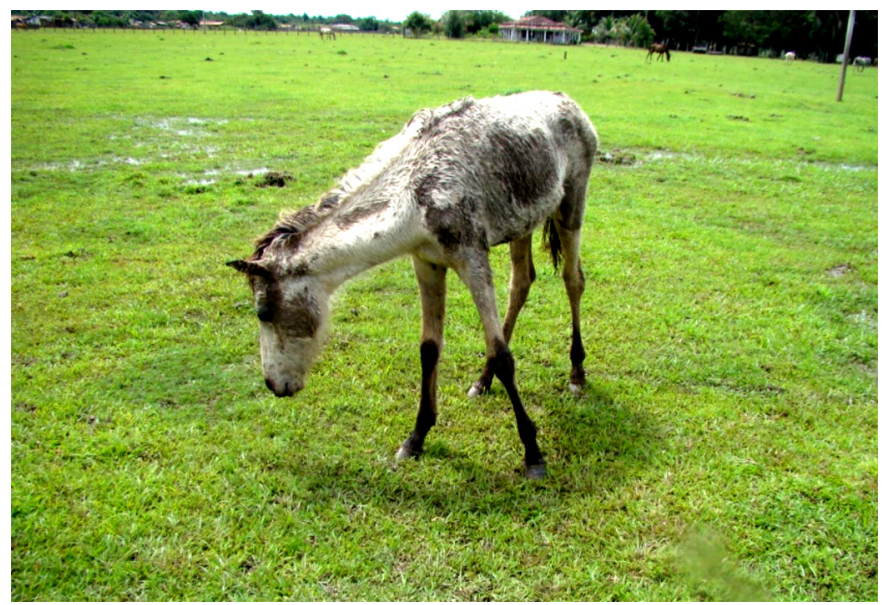

Fig.1. Equino 3 com apatia, cabeça baixa e abdução dos membros.

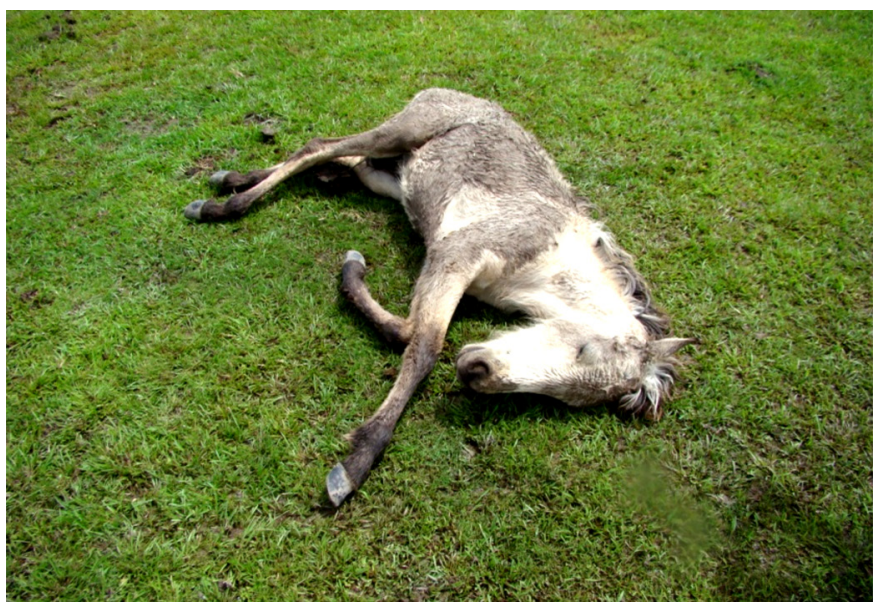

Fig.2. Equino 3 em decúbito lateral.

Quadro 2. Equinos atendidos com sinais clínicos de encefalomielite equina nos meses de maio e junho no município de Cachoeira do Arari, Ilha de Marajó, PA

\begin{tabular}{ccccccc}
\hline $\begin{array}{c}\text { Proprie- } \\
\text { dade }\end{array}$ & $\begin{array}{c}\text { Animal/ficha } \\
\text { clínica/SAP }\end{array}$ & Sexo & Idade & Raça & $\begin{array}{c}\text { Situação no dia do } \\
\text { atendimento }\end{array}$ & Desfecho \\
\hline A & 1/FC 541/SAP 31862 & M & 1,5 anos & Marajoara & Com sinais clínicos leves & Eutanasiado para necropsia \\
B & 2 & M & 2 anos & Marajoara & Com sinais clínicos graves & Morreu, não foi necropsiado \\
C & 3/FC 539/SAP 31834 & F & 6 meses & Marajoara & Com sinais clínicos graves & Eutanasiado para necropsia \\
D & 4 & M & 5 anos & Marajoara & Com sinais clínicos graves & Recuperou-se \\
E & 5/FC 543/SAP 31864 & F & 5 anos & Marajoara & Em fase terminal da doença & Eutanasiado para necropsia \\
F & 6/FC 544/SAP 31865 & F & 4 anos & Marajoara & Morto & Necropsiado \\
F & 7 & M & 11 anos & Puruca & Em recuperação & Recuperou-se \\
F & 8 & M & 3 anos & Marajoara & Em recuperação & Recuperou-se \\
G & 9 & F & 3 anos & Marajoara & Em recuperação & Recuperou-se
\end{tabular}


os membros abduzidos, ora com os membros cruzados e quando tentava se locomover, andava em círculos. Ainda foram observadas, cabeça baixa, levemente rotacionada para a direita, pálpebras cerradas, paralisia da língua (Fig.3), tremores musculares, ranger de dentes, anorexia, desidratação e fezes ressecadas.

0 Equino 4 foi encontrado em estação com o corpo apoiado em uma palmeira (Fig.4). Ao exame clínico observou-se que o animal arrastava as pinças dos membros posteriores, quando em locomoção, e ainda demonstrava sonolência, incapacidade de comer e beber água. Apresentava o tônus da língua diminuído, ausência dos reflexos palatal e de deglutição, assim como diminuição da acuidade visual, demonstrada pela ausência dos reflexos de ameaça e por não desviar de obstáculos. Após oito dias esse equino iniciou um quadro de recuperação e passou a beber e a se alimentar gradativamente.

0 Equino 5, foi encontrado em decúbito esternal, com a cabeça voltada para o flanco e apoiada no solo, em fase terminal da doença (Fig.5). Apresentava ainda incapacidade de se colocar em estação, com paralisia da língua e dificuldade respiratória.

0 Equino 6 foi encontrado morto. Segundo dados obtidos pelo proprietário, o mesmo tinha apresentado andar

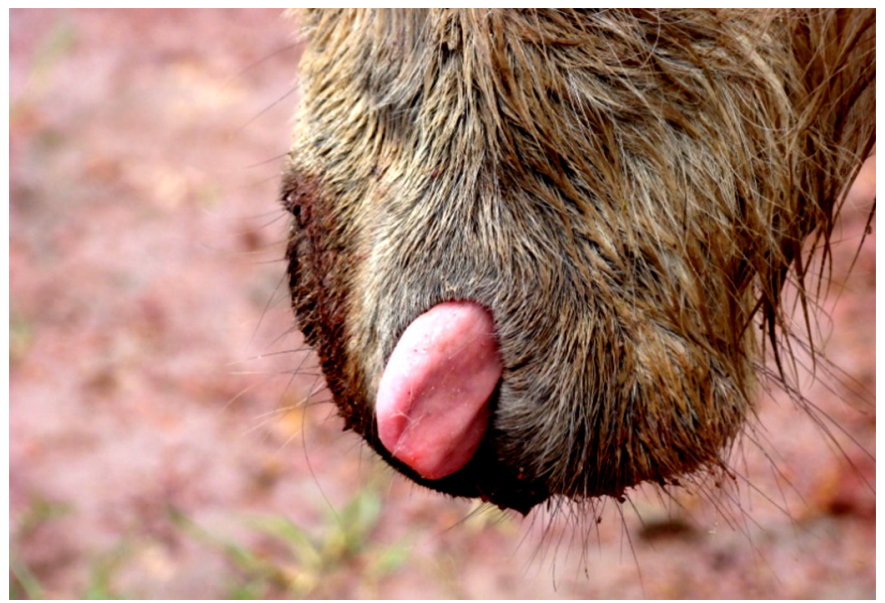

Fig.3. Equino 3 com diminuição do tônus da língua.

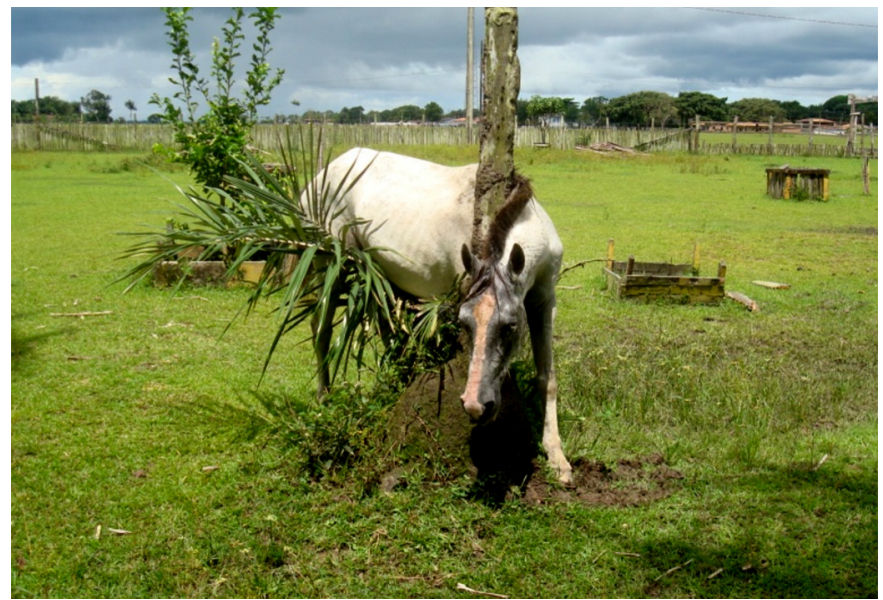

Fig.4. Equino 4 com apatia, a cabeça baixa e o corpo apoiado em uma palmeira para manter o equilíbrio.

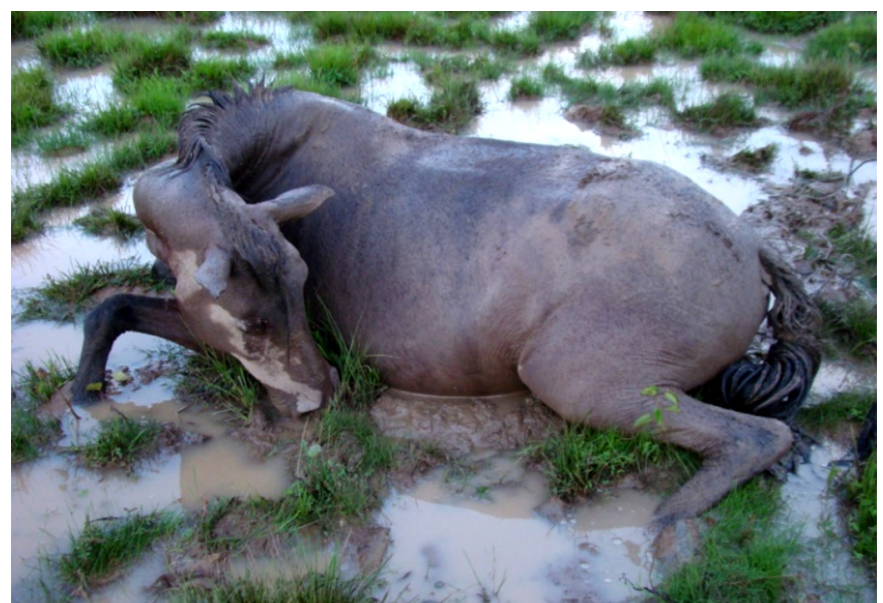

Fig.5. Equino 5 em decúbito esterno-abdominal e em postura de autoauscultação.

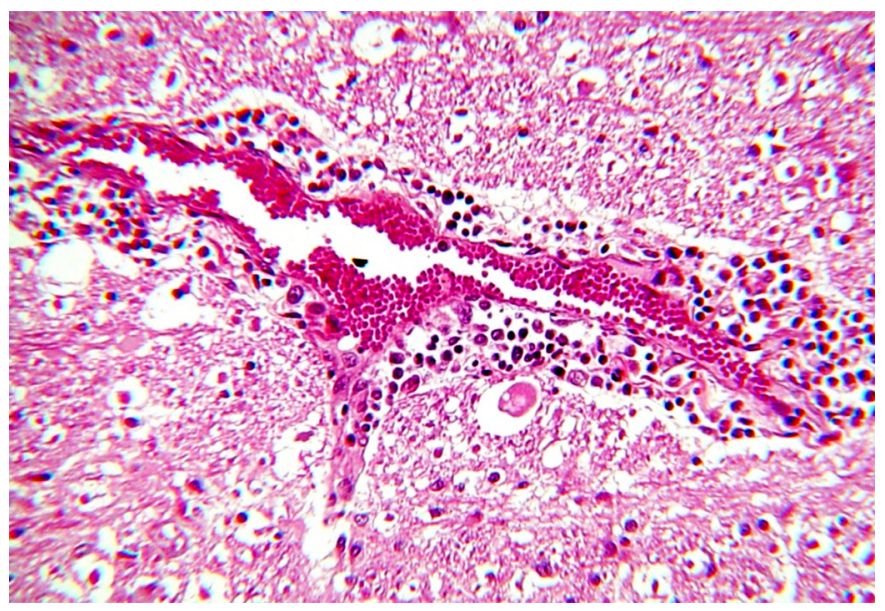

Fig.6. Perivasculite mononuclear em encéfalo de equino, HE, obj.16x.

em círculos há dois dias, e no dia anterior havia caído sem conseguir se levantar.

Os Equinos 7, 8 e 9, que se encontravam em recuperação, apresentavam estado nutricional ruim, leve incoordenação, diminuição do reflexo lingual e feridas nos bordos laterais da língua, o que indicava falta de controle da mesma durante a mastigação.

As alterações macroscópicas observadas durante a necropsia consistiam de hemorragias das leptomeninges e da medula e de aderências das leptomeninges. Não foram observadas alterações macroscópicas nos órgãos abdominais e torácicos.

À histopatologia verificou-se encefalite difusa que afetava principalmente a substância cinzenta, com meningite e coroidite. Foi observada presença de perivasculite mononuclear (Fig.6).

Nos exames de IFD e IIC realizados em São Paulo todos os animais testados (equino 1, 5 e 6) resultaram negativos para raiva. Na reação de Semi-Nested RT-PCR, dois animais (equinos 5 e 6) resultaram positivos para o vírus da Encefalite Equina do Leste.

O teste de IHQ não revelou marcação positiva para raiva, nas secções do SNC dos equinos afetados. 


\section{DISCUSSÃO}

A Ilha de Marajó permanece alagada parte do ano, a água é mantida represada nos campos, o que propicia a proliferação dos mosquitos (Brasil 2007). O surto ocorreu nos meses chuvosos, como também foi relatado por Pimentel et al. (2009), de acordo com os quais cerca de 60 equinos morreram em um surto ocorrido nos municípios de Parnamirim e Exú, em Pernambuco, no mês de junho de 2008, também período chuvoso naquela região. Nos estados do Ceará, Pernambuco e Bahia, Silva et al. (2011) encontraram uma forte relação entre o aumento do índice pluviométrico (o maior em 15 anos) com o surgimento de casos de encefalomielite equina em 2009. Segundo Barros (2007), a atividade dos mosquitos vetores, que transmitem a doença, depende de condições climáticas, como calor e umidade. Por isso, a manifestação clínica da enfermidade em equinos ocorre de forma sazonal, durante a época das chuvas nas regiões tropicais.

O Ministério da Agricultura Pecuária e Abastecimento (MAPA) inclui alguns municípios da Ilha de Marajó como sítios de aves migratórias a serem monitorados periodicamente, por possuírem áreas de concentração de aves silvestres migratórias; esse fator seria importante na epidemiologia de doenças onde essas aves atuariam como reservatórios naturais de agentes infecciosos.

Em nosso estudo foram acometidos equinos de seis meses a 11 anos de idade, de ambos os sexos. Silva et al. (2011) relatam que foram acometidos equinos com seis meses a 16 anos de idade, de ambos os sexos, inclusive de uma mula e um jumento. Essa constatação está de acordo com Thomassian (1996), que afirma que a doença acomete os equídeos, independentemente de sexo e idade. Já Barros (2007), afirma que cavalos jovens são mais susceptíveis.

Dos nove equinos estudados, quatro se recuperaram. Silva et al. (2011) encontraram diferentes taxas de morbidade e letalidade entre duas variantes de EEEV. Morbidade de $61 \%(61 / 100)$ e letalidade de $98,36 \%(60 / 61)$ foram verificadas em um surto estudado no estado de Pernambuco, enquanto que, em outro surto um ano depois, nos estados da Paraíba e do Ceará, a morbidade encontrada foi de $17,5 \%$, e a letalidade foi de $64,8 \%$, o que demonstra que alguns animais podem se recuperar de acordo com a virulência do agente.

Os sinais clínicos foram os mesmos verificados por Pimentel et al. (2009) e Silva et al. (2011), como andar a esmo, cambaleante e em círculo, cegueira, salivação, ranger de dentes, pressão da cabeça contra objetos, quedas, movimentos de pedalagem e decúbito seguido de morte em cerca de três dias, alterações essas que segundo Borges (2004), estão associadas a lesões cerebrais. Os sinais clínicos como, dificuldade de se alimentar e beber, diminuição dos reflexos palpebral, palatal e de deglutição, observados nos equinos do presente estudo, estão relacionados com alterações dos nervos cranianos, cujos núcleos estão localizados no tronco encefálico (Thomassian 1996, Borges 2004).

As lesões como hemorragias das leptomeninges e da medula e aderências das leptomeninges foram semelhantes às descritas por Silva et al. (2011), que descrevem ain- da malácia, principalmente no córtex occipital. No entanto, Barros (2007) e Pimentel et al. (2009) não observaram alterações macroscópicas no SNC.

A encefalite difusa, principalmente na substância cinzenta do cérebro, com meningite e coroidite, encontrada ao exame histopatológico, foi semelhante à encontrada por outros autores em surtos de encefalomielite equina no Brasil (Pimentel et al. 2009, Silva 2011).

A técnica semi-nested RT PCR vem sendo utilizada para identificação dos Alphavirus tanto em mosquitos, pássaros e em equinos (Monroy et al. 1996, Silva et al. 2011). Silva et al. (2011) encontraram $100 \%$ dos animais testados positivos na técnica semi-nested RT PCR. No presente trabalho foi identificado o agente em dois dos três equinos testados.

\section{CONCLUSÕES}

A sintomatologia nervosa apresentada pelos equinos estudados na Ilha de Marajó é compatível com Encefalomielite Equina do tipo Leste; os exames laboratoriais foram necessários para a confirmação do diagnóstico.

A Ilha de Marajó reúne condições ambientais favoráveis ao surgimento da enfermidade, pois seus aspectos geográficos lhe concedem grande importância na epidemiologia de diversas doenças inclusive as encefalomielites virais.

Agradecimentos.- À Dra. Ivanete Kotait, Seção de Diagnóstico do Instituto Pasteur, São Paulo, pela realização e interpretação dos exames laboratoriais para raiva e encefalomielite equina.

\section{REFERÊNCIAS}

Alice F.J. 1956. Infecção humana pelo vírus "leste” da encefalite equina. Bolm Inst. Biológico da Bahia 3:3-9.

Barros C.S.L. 2007. Encefalomielites virais dos equinos, p.103-106. In: Riet-Correa F., Schild A.L., Lemos R.A.A. \& Borges J.R. (Eds), Doenças de Ruminantes e Equídeos. Vol.2. 3aㅡ ed. Pallotti, Santa Maria.

Bauer R.W., Gill M.S. \& Poston R.P. 2005. Naturally occurring Eastern equine encephalitis in a Hampshire wether. J. Vet. Diagn. Invest. 17:281285.

Borges A.S. 2004. Semiologia do sistema nervoso de grandes animais, p.506-526. In: Feitosa F.L.F. (Ed.), Semiologia Veterinária: a arte do diagnóstico. Roca, São Paulo.

Brasil 2007. Plano de Desenvolvimento Territorial Sustentável para o Arquipélago do Marajó: resumo executivo da versão preliminar para discussão nas consultas públicas. Governo Federal, Grupo Executivo Interministerial, Brasília. Editora do Ministério da Saúde, Brasília.

Cardoso E.C. \& Pereira W.L.A. 2002. Mineral deficiency of buffaloes from Marajó Island, North of Brazil: current situation and perspectives. Proc. Buffalo Symposium of Americas, Belém, PA. ABCB/APCB, Belém, p.4755.

Carneiro V.A. 1937. Encefalomielite infecciosa dos equídeos do Brasil. Arqs Inst. Biológico, São Paulo, 8:115-134.

Casseb A.R. 2010. Soroprevalência de anticorpos e padronização no teste ELISA sanduiche indireto para 19 tipos de arbovírus em herbívoros domésticos. Tese de Doutorado, Universidade Federal do Pará, Belém.

Cunha E.M.S., Villalobos E.M.C., Nassar A.F.C., Lara M.C.C.S.H., Peres N.F., Palazzo J.P.C., Silva A., De Stefano E. \& Pino F.A. 2009. Prevalência de anticorpos contra agentes virais em equídeos no sul do estado de São Paulo, Instituto Biológico, Centro de Pesquisa e Desenvolvimento de Sanidade Animal. Arqs Inst. Biológico, São Paulo, 76(2):165-171.

Elvinger F.A.D., Liggett A.D., Tang K.N., Harrison L.R., Cole Jr J.R., Baldwin C.A. \& Nessmith W.B. 1994. Eastern equine encephalomyelitis virus infection in swine. J. Am. Vet. Med. Assoc. 205:1014-1016. 
Farrar M.D., Miller D.L., Baldwin C.A., Stiver S.L. \& Hall C.L. 2005. Eastern equine encephalitis in dogs. J. Vet. Diagn. Invest. 17:614-617.

Fernández Z., Richartz R., Travassos-da-Rosa A.P.A. \& Soccol V.T. 2000. Identificação do vírus causador de encefalomielite equina, Paraná, Brasil. Revta Saúde Pública 34(3):232-235.

Fields B.N., Knipe D.M. \& Howley P.M. 1996. Fields Virology. $3^{\text {rd }}$ ed. Lippincott-Raven, Philadelphia.

Heinemann M.B., Souza M.C.C., Cortez A., Ferreira F., Homem F., Ferreira-Neto J.S., Soares R.M., Cunha E.M.S. \& Richtzenhain L.J. 2006. Soroprevalência da encefalomielite equina do leste e do oeste no Município de Uruará, PA, Brasil. Braz. J. Vet. Res. Anim. Sci. 43:137-139.

Iversson L.B., Silva R.A. \& Barros V.L. 1993. Circulation of Eastern equine encephalitis, Western equine encephalitis, Ilhéus, Maguari and Tacaiuma viruses in equines of the Brazilian Pantanal, South America. Revta Inst. Med. Trop., São Paulo, 35:355-359.

Kotait I., Brandão P.E. \& Carrieri M.L. 2006. Vigilância Epidemiológica das Encefalites Equinas. Instituto Pasteur, Coordenadoria de Controle de Doenças, Secretaria de Estado da Saúde de São Paulo, IP/CCD/SES-SP, Ano 3, Número 29.

Kotait I., Peixoto Z.M.P., Coimbra T.L.M., Cunha S.E.M., Queiroz L.H. \& Macruz R. 1992. Isolamento e identificação do vírus da encefalomielite equina, tipo leste, em equinos do Estado de São Paulo, Brasil. Arqs Inst. Biológico, São Paulo, 59:37-41.

Lennette E.H. \& Fox J.P. 1943. Anticorpos neutralizantes para a amostra leste do vírus de encefalomielite equina em equídeos no Brasil. Mem. Inst. Oswaldo Cruz 38(1):85-92.

Monroy A.M., Scott T.W. \& Webb B.A. 1996. Avaliação de reverse transcriptase reação em cadeia da polimerase para a detecção de vírus de encefalomielite equina do leste durante a vigilância do vetor. J. Med. Entomol. 33:449-457.

Nilsson M.R. \& Sugay W. 1962. Ocorrência da encefalomielite equina em Itaporanga, Estado de São Paulo. Arqs Inst. Biológico, São Paulo, 29:6368.

Pfeffer M., Proebster B., Kinney R.M. \& Kaaden O.R. 1997. Genus-specific detection of alphaviruses by a semi-nested reverse transcription-polymerase chain reaction. Am. J. Trop. Med. Hyg. 57:709-718.

Pimentel L.A., Oliveira D.M., Galiza G.J.N., Rego R.O., Dantas A.F.M. \& Riet-Correa F. 2009. Doenças do sistema nervoso central de equídeos no semi-árido. Pesq. Vet. Bras. 29(7):589-597.

Silva M.L.C.R., Galiza G.J.N., Dantas A.F.M., Oliveira R.N., Iamamoto K., Achkar S.M. \& Riet-Correa F. 2011. Outbreaks of Eastern equine encephalitis in northeastern Brazil. J. Vet. Diagn. Invest. 23(3):570-575.

Thomassian A. 1996. Enfermidades Infecciosas, p.598-599. In: Thomassian A. (Ed.), Enfermidades dos Cavalos. Editora Varela, São Paulo.

Vasconcelos P.F.C., Travassos-da-Rosa J.F.S., Travassos-da-Rosa A.P.A., Degallier N., Pinheiro F.P. \& Sá-Filho G.C. 1991. Epidemiologia das encefalites por arbovírus na Amazônia Brasileira. Revta Inst. Med. Trop., São Paulo, 33(6):465-476. 